\title{
Estimating the terrestrial carbon pools of the former Soviet Union, conterminous U.S., and Brazil
}

\author{
David P. Turner ${ }^{1, *}$, Jack K. Winjum ${ }^{2}$, Tatyana P. Kolchugina ${ }^{3}$, Ted S. Vinson ${ }^{3}$, \\ Paul E. Schroeder ${ }^{4}$, Donald L. Phillips ${ }^{5}$, Michael A. Cairns ${ }^{5}$ \\ ${ }^{1}$ Department of Forest Science, Oregon State University, Corvallis, Oregon 97331, USA \\ ${ }^{2}$ National Council for Air and Stream Improvement, USEPA National Health and Environmental Effects Research \\ Laboratory/Western Ecology Division, 200 SW 35th Street, Corvallis, Oregon 97333, USA \\ ${ }^{3}$ Department of Civil Engineering, Oregon State University, Corvallis, Oregon 97331, USA \\ ${ }^{4}$ Dynamac Corporation, USEPA National Health and Environmental Effects Research Laboratory/Western Ecology Division, \\ 200 SW 35th Street, Corvallis, Oregon 97333, USA \\ ${ }^{5}$ U.S. Environmental Protection Agency, National Health and Environmental Effects Research Laboratory/Western Ecology \\ Division, 200 SW 35th Street, Corvallis, Oregon 97333, USA
}

\begin{abstract}
Terrestrial-carbon (C) pool sizes are of interest in relation to quantifying current sources and sinks of $C$, and evaluating the possibilities for future $C$ sequestration or release by the biosphere. In this study, the $\mathrm{C}$ pools in the terrestrial ecosystems of the former Soviet Union $\left(\mathrm{SU}_{\mathrm{f}}\right)$, conterminous United States $\left(\mathrm{US}_{c}\right.$ ), and Brazil were estimated for a nominal 1990 base year. Data sources included recent vegetation maps, resource inventories (particularly for forests), and published values for $C$ densities (mass per unit area). Methodology varied by nation depending upon data availability but generally consisted of identifying a suitable land cover classification system, quantifying the area of each land cover type using traditional mapping approaches or satellite remote sensing, and assigning a mean $\mathrm{C}$ density to each cover type with separation by phytomass, litter plus coarse woody debris, and soil. Total organic $\mathrm{C}$ for the 3 geographic areas was estimated at $839 \mathrm{Pg}\left(\mathrm{Pg}=\mathrm{g} \times 10^{15}\right) \mathrm{C}$ in $1990,38 \%$ of a literature-based estimate of the global terrestrial-C pool on an area representing $28 \%$ of the world's lands (excluding Antarctica). The soil $\mathrm{C}$ pool was the largest component in the $\mathrm{SU}_{1}\left(84 \%\right.$ of the total) and $\mathrm{US}_{\mathrm{C}}$ $(76 \%)$ but not in Brazil $(47 \%)$. Correspondingly, the proportion as phytomass was greatest in Brazil $(48 \%)$ compared to the $\mathrm{SU}_{\mathrm{I}}(10 \%)$ and $\mathrm{US}_{\mathrm{c}}(17 \%)$. The forest land cover class contained by far the largest proportion of $\mathrm{C}$ among the land cover classes except in the $\mathrm{SU}_{f}$ where peatlands were dominant with $37 \%$ of the total. The 2 largest $\mathrm{C}$ pools isolated in this study are potentially long-term sources of $\mathrm{C}$ to the atmosphere: soil $\mathrm{C}$ in peatlands of $\mathrm{SU}_{\mathrm{f}}(212 \mathrm{Pg})$ which may be lost via climate change, and phytomass $C$ in the tropical-moist forests of Brazil $(105 \mathrm{Pg})$ which may be lost via deforestation.
\end{abstract}

KEY WORDS: Carbon pools · Terrestrial ecosystems · Former Soviet Union · United States · Brazil

\section{INTRODUCTION}

The storage of carbon (C) in the terrestrial biosphere as biomass, detritus, and humic compounds is about 3 times larger than the pool of $\mathrm{C}$ as $\mathrm{CO}_{2}$ in the atmosphere (Schimel 1995). Studies of $\mathrm{CO}_{2}$ concentration and isotopic composition in the ice core record indicate

•E-mail: turnerd@fsl.orst.edu large transfers of $\mathrm{C}$ from the terrestrial biosphere to the atmosphere over the last 3 centuries. These transfers have contributed about half of the approximately 80 ppm rise in the atmospheric $\mathrm{CO}_{2}$ concentration over that period (Siegenthaler \& Oeschger 1987). Recognition of the importance of the terrestrial biosphere in the global $\mathrm{C}$ cycle has focused increasing attention on quantifying terrestrial-C pools and flux (Dixon et al. 1994, Denning et al. 1995, Turner et al. 1997). 
Knowledge of $\mathrm{C}$ pools is important for understanding the current $\mathrm{C}$ flux and the possible future transfers of $\mathrm{C}$ between the terrestrial biosphere, the atmosphere, and the oceans. Methods of $\mathrm{C}$ flux estimation based on differences in $C$ pools at 2 points in time (e.g. Kauppi et al. 1992) rely heavily on accurate estimates of $\mathrm{C}$ pools. Projections of future $\mathrm{CO}_{2}$ emissions from the biosphere likewise depend on knowledge of current $\mathrm{C}$ pool sizes in order to establish how long processes such as deforestation can be sustained (Houghton 1990). The effort to estimate actual $C$ pools is also complementary to studies of potential $C$ pools based on spatially distributed biogeochemical models (McGuire et al. 1992).

One approach to improving estimates of the global terrestrial-C pools and flux is to make nation-by-nation estimates and aggregate the results for a world total (Subak et al. 1993). The fact that resource inventories are usually maintained at the national level provides a strong rationale for the nation-by-nation approach. In addition, it is increasingly clear that humankind has become a dominant influence on the $C$ pools of the world. Influences are primarily through activities such as conversion of forests to agriculture and harvest of timber resources for wood products (Laarman \& Sedjo 1992). Public policies that determine land use and the associated effects on $\mathrm{C}$ pools and flux are generally developed at the national level, making national borders a useful basis for stratification.

In this context, the former Soviet Union ( $\left.\mathrm{SU}_{\mathrm{f}}\right)$, Brazil, and the conterminous United States $\left(\mathrm{US}_{\mathrm{c}}\right)$ are among the 5 largest national-level areas (i.e. first, fourth, and fifth respectively, with Canada second and China third; NYT 1988). These 3 nations differ widely in climate, patterns of land use, and data availability. Furthermore, they represent important areas within the boreal, temperate, and tropical regions of the world. The $\mathrm{SU}_{\mathrm{f}}$ contains $55 \%$ of the boreal and $15 \%$ of the temperate regions; the $\mathrm{US}_{\mathrm{c}}, 13 \%$ of the temperate region; and Brazil, $1 \%$ of the temperate and $16 \%$ of the tropical regions (Winjum et al. 1993). In this paper, we describe results of an early attempt to estimate the terrestrial-C pool at the national level for these nations.

\section{METHODS}

To quantify national-level $\mathrm{C}$ pools, a nation is first divided into ecosystem and land-use types. Ostensibly, selected types have a uniform vegetative cover or land use, and their areas can be measured with reasonable accuracy. Vegetation maps are common sources for this information. Second, the average amount of $\mathrm{C}$ per unit area ( $C$ density) is obtained from the literature, or if unavailable, from new ecological field studies or inventories. Third, the area of each type is multiplied by its respective $\mathrm{C}$ density and results are summed across all types. Units of measure are typically megagrams of $\mathrm{C}$ per hectare $\left(\mathrm{Mg} \mathrm{C} \mathrm{ha} \mathrm{C}^{-1}\right)$ for densities and petagrams $\left(10^{15} \mathrm{~g}\right)$ of $\mathrm{C}(\mathrm{Pg} \mathrm{C})$ for national-level totals.

The approach might seem straightforward: biogeographers have been producing vegetation maps for almost 2 centuries now and the introduction of satellite remote sensing has greatly improved their capabilities. Ecologists have likewise been amassing data on $\mathrm{C}$ densities for the major ecosystems of the world for many decades. However, practice is generally compromised by problems such as lack of reliable vegetation maps at appropriate scales, land-use changes, gaps in ecological knowledge (e.g. belowground-C densities), and questionable data quality.

The following sections describe 3 variations of the general approach associated with studies of the national-C pools for $\mathrm{SU}_{i}, \mathrm{US}_{c}$, and Brazil (Cairns et al. 1995). The studies focused on a nominal base year of 1990 and used $C$ densities that represented above- and belowground living phytomass, dead organic matter [i.e. litter and coarse woody debris (CWD)], and soil organic $\mathrm{C}$ (to a depth of $1 \mathrm{~m}$ unless otherwise noted; $\mathrm{C}$ in soil carbonates was not included). Definitions of key ecosystem and land-use types were as follows.

Forests. At the outset, we found that definitions of forests varied considerably among the 3 nations in this study. In the $\mathrm{SU}_{\mathrm{f}}$, forested land (herein called 'forests') is defined as areas with stocking level (in terms of basal areaj greater than $30 \%$ of full stocking at the local reference level. The forest category is subdivided into 'closed forests' - including taiga, mixed conifer and deciduous, and deciduous types - and woodlands which include the forest-tundra and forest-steppe formations. Typically, 50 to $80 \%$ of the landscape is forested in the closed forest class (Vorobyov 1985). The USDA (U.S. Department of Agriculture) Forest Service defines forests as tree-covered lands capable of producing at least $1.4 \mathrm{~m}^{3} \mathrm{ha}^{-1}$ of industrial wood per year (Haynes 1990). In Brazil, resource managers have begun inventorying areas of mature and secondary forests by remote sensing but precise data on growth rates or stocking levels are limited (Brown \& Lugo 1992). The nation's definition of forests is generally consistent with the FAO definition, i.e. lands with treecrown cover equal to or greater than 20\% (FAO 1995). The 'forest' ecosystem and land-use type in Brazil is further segregated into various combinations of forests that are closed, open, secondary, degraded or mixed with agriculture (discussed below). The forest areas in all 3 nations included those that were available for commercial harvests and held in reserves, publicly and privately owned, plus natural stands (primary or secondary) and plantations. Tree species consisted of hardwoods, conifers, or mixtures 
Woodlands. This ecosystem type includes lands occupied by trees, but with less growth capacity, or forest cover across the landscape, than noted in the above definitions. In the $\mathrm{SU}_{\mathrm{f}}$, woodlands are defined as hav. ing $\leq 25 \%$ forest cover and appear scattered in the forest-tundra and forest-steppe formations. An example of woodlands in the US $\mathrm{US}_{\mathrm{c}}$ is the pinyon-juniper type of the southwest. In Brazil, the woodlands are typically associated with a dry climate but may achieve relatively high crown cover.

Non-forests. In our studies, this land-use type included arable lands used for agriculture, e.g. croplands (including orchards) with $C$ densities assumed to be at peak levels before harvests. Also included as non-forest types were grasslands, pasturelands, peatlands, and rangelands. Peatlands are a particularly significant ecosystem type in the boreal regions where edaphic conditions are characterized by a continuously high water table, resulting in the accumulation of organic matter (Kauppi et al. 1997).

\subsection{The former Soviet Union}

The $\mathrm{SU}_{\mathrm{f}}$ stretches across nearly $140^{\circ}$ of longitude compared with about $60^{\circ}$ for the $\mathrm{US}_{\mathrm{C}}$ and $40^{\circ}$ for Brazil
(Fig. 1). This land expanse results in ecosystem and land-use types that, even with the same vegetation cover and soils, often have different $C$ densities for phytomass, litter-CWD, and soil. Consequently, georegions were defined by dividing the area of the $\mathrm{SU}_{\mathrm{f}}$ from east to west by 7 transects running in roughly north-south directions (Kolchugina \& Vinson 1993c). The georegions, which correspond to those commonly used in the $\mathrm{SU}_{f}$ for other purposes, were: European (West, Central, Eastern), Siberia (West, Central, and Eastern), Near-Pacific, and Kazakhstan.

Thematic maps available for the $\mathrm{SU}_{\mathrm{f}}$ were the basis for measuring the areas of ecosystems and land-use types within georegions. A global soil-vegetation map (scale 1:15000000; Ryabchikov 1988) was used to evaluate Russia, Ukraine, Belorus, Moldova, Kazakhstan, and the Baltic states. The primary ecosystem types identified using this map were the polar desert, tundra, foresttundra/sparse-taiga, taiga, mixed-deciduous forest, forest-steppe and warm-temperate woodland, steppe, and desert-semidesert (Kolchugina \& Vinson 1993c).

The total area of forests in $\mathrm{SU}_{1}$ (i.e. forest stands with stocking of $30 \%$ and greater) covers $814.3 \times 10^{6}$ ha (USSR 1990). The areas of woodlands were distinguished from closed forest areas based on the soil-vegetation map of Ryabchikov (1988). This gave a ratio of

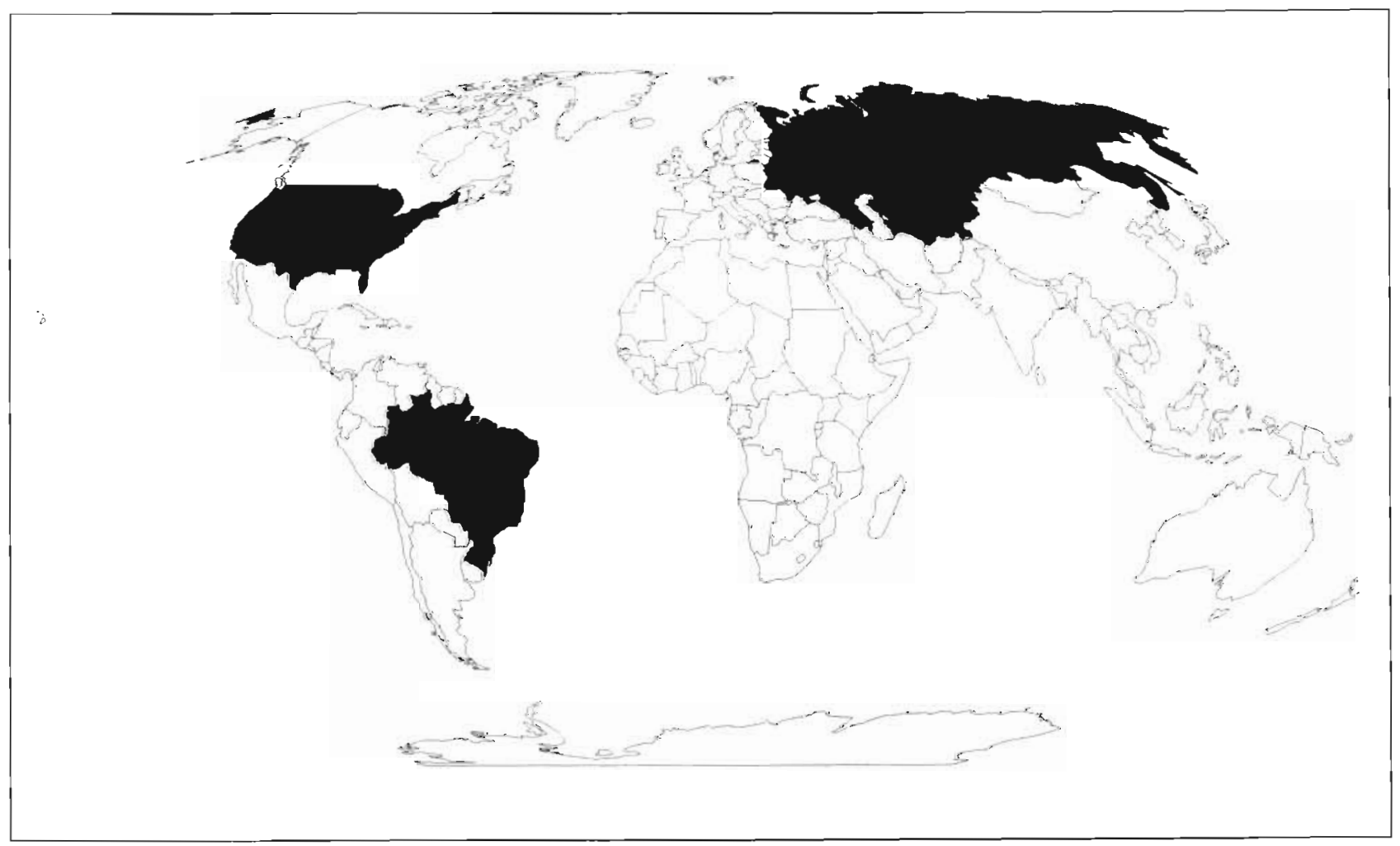

Fig. 1. Relative sizes of the former Soviet Union, conterminous United States, and Brazil on an equal-area projection map of the world centered on the Greenwich meridian 
Table 1. Areas and $\mathrm{C}$ densities of major ecosystems and land-use types of the $S \mathrm{f}_{\mathrm{f}}$ for 1990 . na: not applicable

\begin{tabular}{|c|c|c|c|c|c|c|}
\hline \multirow{2}{*}{ Ecosystem and land-use type ${ }^{d}$} & \multirow{2}{*}{ Area (Mha) } & \multicolumn{4}{|c|}{$\mathrm{C}$ density $\left(\mathrm{Mg} \mathrm{C} \mathrm{ha}^{-1}\right)$} & \multirow{2}{*}{$\begin{array}{l}\text { C pool } \\
(\mathrm{PgC})\end{array}$} \\
\hline & & $\begin{array}{l}\text { Phyto- } \\
\text { mass }\end{array}$ & $\begin{array}{l}\text { Litter- } \\
\text { CWD }\end{array}$ & Soil & Total & \\
\hline Polar desert and tundra & $234.1^{\mathrm{b}}$ & $8.6^{\mathrm{b}}$ & $16.7^{\mathrm{b}}$ & $194.8^{\mathrm{b}}$ & 220.1 & 51.5 \\
\hline Forest & $623.2^{c}$ & $69.5^{c}$ & $30.8^{c}$ & $121.5^{1}$ & 221.8 & 138.2 \\
\hline Woodland & $191.1^{\mathrm{C}}$ & $33.5^{c}$ & $15.7^{c}$ & $123.0^{c}$ & 172.2 & 32.9 \\
\hline Boreal and temperate grasslands (including deserts) & $692.0^{\mathrm{b}}$ & $7.1^{\mathrm{b}}$ & $7.9^{\mathrm{b}}$ & $162.6^{b}$ & 177.6 & 122.9 \\
\hline Peatland & $164.8^{\mathrm{d}}$ & $20.0^{\mathrm{d}}$ & $n a^{d}$ & $1299.2^{d}$ & 1319.2 & 220.2 \\
\hline Arable land & $227.0^{\mathrm{e}}$ & $3.1^{\mathrm{e}}$ & $0^{\mathrm{e}}$ & $153.3^{e}$ & 156.4 & 35.5 \\
\hline Total & 2132.2 & & & & & 601.2 \\
\hline \multicolumn{7}{|c|}{ 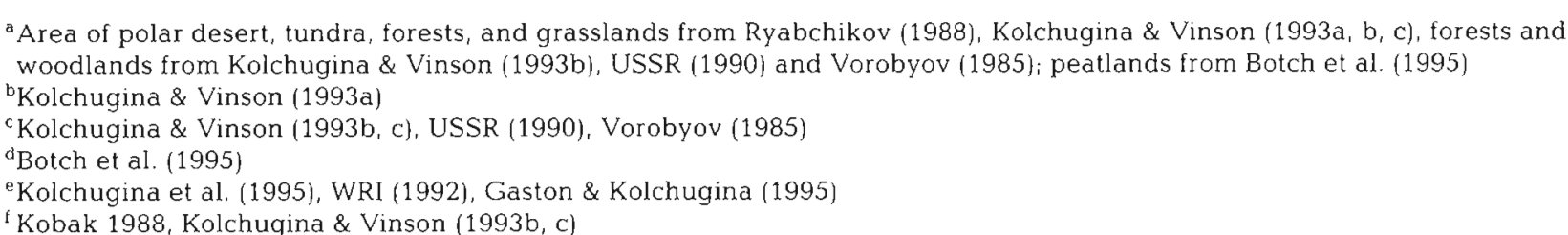 } \\
\hline
\end{tabular}

closed forests to woodlands of $76: 24$ which we applied to the $814.3 \times 10^{6}$ ha of total forests to get area estimates of woodlands and closed forests of $191.1 \times 10^{6}$ and $623.2 \times 10^{6}$ ha, respectively. There is an additional category of lands with some trees considered 'thin forests', i.e. with stocking levels below $30 \%$, totaling approximately $58 \times 10^{6} \mathrm{ha}$

The area of peatlands was from a recent assessment by Botch et al. (1995) based upon state-inventory data supplemented by aerial photographs and large-scale maps (formerly classified). The area of agricultural lands (croplands, haylands, and pasturelands) was from Kolchugina et al. (1995) and the World Resources Institute (WRI 1992).

Ultimately, all maps and land areas were superimposed using a geographic information system (GIS) to identify ecoregions (i.e. ecosystems based on the soilvegetation associations isolated within specific georegions). In this manner, the $\mathrm{SU}_{\mathrm{f}}$ could be subdivided into 6 broad ecosystem and land-use types, and for each, we could determine the area (Table 1; Kolchugina \& Vinson 1993c).

Estimated $C$ densities for forests and woodlands were based on data for the growing stock volumes of commercial timber throughout the nation (USSR 1990 , Kolchugina \& Vinson 1993a, 1995). The estimate required conversion of growing stock volume to $\mathrm{C}$ densities for: (1) the main tree stem; (2) parts of trees other than stems; (3) ecosystem components other than trees; and (4) CWD accumulation. As described in Kolchugina \& Vinson (1993b), the conversion factors used in this analysis were from Isayev et al. (1993).

Carbon densities for phytomass and litter in nonforested ecoregions were based upon data compiled by Bazilevich (1986) (Kolchugina \& Vinson 1993a, b, c).
The source of this database was a set of studies associated with approximately 1500 vegetation complexes (sites) in the $\mathrm{SU}_{\mathrm{f}}$. These studies consisted of periodic observations recorded during the 2 decades before about 1985 on a broad array of ecosystem variables, particularly aboveground phytomass. This made the database a comprehensive source of information on common ecosystem types in the $\mathrm{SU}_{\mathrm{f}}$. For this analysis, the $C$ content of all plants was assumed to be $50 \%$ of the phytomass values (Kobak 1988). For some ecosystem and land-use types, estimates of $C$ densities required further assumptions, e.g. the phytomass of $\mathrm{SU}_{\mathrm{f}}$ arable lands was estimated from data on economic yields of major $\mathrm{SU}_{\mathrm{f}}$ crops by applying harvest indexes (Gaston \& Kolchugina 1995).

Estimates of soil organic matter (SOM) for polar deserts, tundras, forests, and grasslands, were based on $\mathrm{C}$ densities from Kobak (1988) and areas by soil type (Ryabchikov 1988, Kolchugina \& Vinson 1993a, c; Table 1). The area-weighted average SOM C content of the arable lands was calculated from the distribution of associated soil types (Cherdantsev 1961, Ryabchikov 1988) within the $\mathrm{SU}_{\mathrm{f}}$ as described in Kolchugina et al. (1995). For current conditions in the arable lands, Gaston et al. (1993) estimates a loss of $24 \%$ (an areaweighted average) of the initial $C$ content. This estimate, applied to major soil types in the $\mathrm{SU}_{1}$, comes from an equation developed by Mann (1986) that predicts the current $\mathrm{C}$ content of cultivated soil as a function of the initial $\mathrm{C}$.

Bazilevich (1986) and Botch et al. (1995) were the sources of $\mathrm{C}$ densities for litter and SOM (i.e. peat) in peatlands. The SOM data generally referred to $1 \mathrm{~m}$ depths in mineral soils. In the deep chernozem soils, however, total SOM content was based on measure- 
ments at depths greater than $1 \mathrm{~m}$. The depth of the peat layer in peatlands is often $5 \mathrm{~m}$ or more. We obtained the $\mathrm{C}$ content from the federal peat inventory, published literature on noncommercial peatlands. engineering reports, and recent field observations (Bazilevich 1986, Botch et al. 1995). These data represent the full range of SOM densities, i.e. not biased to peak conditions.

\subsection{The conterminous United States}

For the $\mathrm{US}_{\mathrm{C}}$, the continental land area was subdivided into the following 5 ecosystem and land-use types used by the USDA Resource Planning Act (RPA) reports (SCS 1987): forests, woodlands, rangelands, pasturelands, and croplands (Table 2). A sixth type, simply called 'other lands', included all remaining areas, such as towns and cities, not included in the 5 larger types. Alaska was not included in the analysis because of data limitations at the time of the study. The approach for estimating $\mathrm{C}$ pools varied according to ecosystem and land-use type (Turner \& Baumgardner 1995).

Forest estimates used 1990 forest-inventory data for the $\mathrm{US}_{\mathrm{c}}$. A forest inventory for private lands in 1990 was prepared as part of the USDA Forest Service 1993 RPA assessment (J. Mills, USDA Forest Service, Portland, OR, pers. comm.; Haynes 1990). The inventory was based on survey data from regional Forest Inventory and Analysis (FIA) work units (USDA 1992) and was structured in the framework of the ATLAS inventory projection model (Mills \& Kincaid 1992). The ATLAS-based inventory included information on the area and stocking level within each age class for 422 combinations of region, ownership, forest type, productivity level and timber management intensity. Peterson \& Turner (1993) discussed the uncertainty associated with the FIA inventories.

Data for the age-class distributions on public lands within each forest type existed for some areas, but had not been compiled on a national scale. An estimate of the age-class distributions and stocking levels on public lands in the $\mathrm{US}_{\mathrm{C}}$ was therefore developed in part from data in recent state-level studies. These reports collated age-class data for national forests, reserved lands and other public lands in the Pacific Northwest region, where the largest volumes of public timber in the $\mathrm{US}_{\mathrm{c}}$ are found (MacLean et al. 1991, Sessions 1991, Adams et al. 1992). Other sources of data included the areas and volumes by forest type on public lands (Waddell et al. 1989) and the age-class distributions on private lands (Turner et al. 1993).

Estimates for the total $C$ pool in forests combined: (1) data on the area and stocking level of each age class within each inventory type (i.e. the forest inventory), and (2) the $\mathrm{C}$ densities for the tree, understory, litter, and soil components in a stand-level $\mathrm{C}$ budget associated with each inventory type. We used the Forest Carbon Model described by Turner et al. $(1993,1995)$ to estimate the pool of CWD debris in each age class. Literature studies (e.g. Vogt et al. 1986) provided the basis for estimating the $C$ in the forest floor and understory over the course of stand development. To arrive at representative soil- $\mathrm{C}$ pools for each forest type, a map of soil-C density (Kern 1994) was overlaid with the spatial distribution of each forest type (Eyre 1980). In accord with the recent literature (Alban \& Perala 1992, Johnson 1992), we assumed that soil $C$ was stable over the course of stand development.

The area of woodlands, i.e. forested lands with potential growing stock accumulation rates of less than $1.4 \mathrm{~m}^{3} \mathrm{ha}^{-1} \mathrm{yr}^{-1}$ (Waddell et al. 1989, Powell et al. 1993), was obtained from Peterson (1993). For woodland phytomass, this study used an average value of $13.0 \mathrm{Mg} \mathrm{C}$ $\mathrm{ha}^{-1}$ (Peterson 1993). There was no database from which to estimate woodland soil-C density. As a preliminary estimate, we assigned a value midway between the average for forest and rangeland soil $C$ to woodlands.

Table 2. Area and $\mathrm{C}$ density by ecosystem and land-use type for the US $\mathrm{C}_{\mathrm{c}}$ during 1990. na: not applicable

\begin{tabular}{|c|c|c|c|c|c|c|}
\hline \multirow[t]{2}{*}{ Ecosystem and land-use type } & \multirow[t]{2}{*}{ Area (Mha) } & \multicolumn{4}{|c|}{$\mathrm{C}$ density $\left(\mathrm{Mg} \mathrm{C} \mathrm{ha}^{-1}\right)$} & \multirow[t]{2}{*}{ C pool (Pg C) } \\
\hline & & Total phytomass & Litter-CWD & Soil & Total & \\
\hline Forest & 200.7 & 63.1 & 30.2 & 91.1 & 184.4 & 36.9 \\
\hline Woodland ${ }^{\mathrm{d}}$ & 41.2 & 13.0 & na & 78.6 & 91.6 & 3.7 \\
\hline Pastureland ${ }^{b}$ & 54.0 & 4.3 & na & 87.6 & 91.9 & 4.9 \\
\hline Rangeland ${ }^{\mathrm{b}}$ & 246.8 & 2.3 & na & 66.2 & 68.5 & 16.9 \\
\hline Cropland & 154.7 & 5.3 & na & 105.2 & 110.5 & 17.1 \\
\hline Other lands ${ }^{\mathrm{b}}$ & 68.2 & 2.5 & na & 86.3 & 88.8 & 6.1 \\
\hline Total & 765.6 & & & & & 85.6 \\
\hline
\end{tabular}


The areas of rangelands, pasturelands, and croplands in the US C $_{c}$ were obtained from the USDA (1989). We assumed that the $C$ pools of the litter-CWD for all 3 ecosystem and land-use types were negligible. A further assumption was that the $C$ pool in vegetation was the same as the net primary production (NPP). The effect of that assumption placed an upper bound on the phytomass pool rather than an annual average. It was also assumed that the annual NPP was balanced by annual decomposition or fire [i.e. net ecosystem productivity (NEP) equal to zero]. The NPP for nonforested lands was estimated using land-cover data from the 1982 Natural Resources Inventory (NRI) database (SCS 1987) and several different NPP databases (King 1993).

Soil C for rangelands, pasturelands, and croplands was based on the national soil C map of Kern (1994). In that study, representative values for soil taxonomic types were developed from the SCS National Soil Survey Laboratory Pedon Database and mapping of soil taxonomic units was from the 1982 NRI. The estimates were adjusted for soil depth and rock fragments of the subsoil by data from the SCS Soil-5 database. Rock fragment content for the surface horizon was based on the texture modifier of the 1982 NRI. Average soil C density for each land cover class was based on values of all land classified into that class by the NRI.

Again, the $\mathrm{C}$ pools for each ecosystem or land-use type were estimated by multiplying the average densities by the area. The sum of all 6 pools gave the estimated $\mathrm{C}$ pool for the terrestrial ecosystems of the $\mathrm{US}_{\mathrm{C}}$ (Table 2).

\subsection{Brazil}

For Brazil, we obtained the major ecosystem and land-use types from a recent vegetation map of South America (Stone et al. 1994, Winjum \& Schroeder 1995). The map was based primarily on Advanced Very High Resolution Radiometer (AVHRR) satellite data from the late 1980s and early 1990 s with a resolution of approximately $1.1 \mathrm{~km}$. These AVHRR data were supplemented by higher resolution satellite imagery, photographs, earlier potential vegetation maps, and field observations (Schroeder \& Winjum 1995).

Two of the mapped ecosystem and land-use typesthe 2 degraded forest classes - were subdivided in order to account for within-type variability in $\mathrm{C}$ density. Stone et al. (1994) defined 'degraded' to include 'areas that have been altered or converted from natural or primary vegetation by man, grazing, or for cultivation'. The vegetation of degraded-forest classes is very heterogeneous and can include land uses with quite different $\mathrm{C}$ densities. Therefore, the degraded- tropical-moist forest (TMF) type, which consisted of an estimated $42.5 \times 10^{6}$ ha within the Amazon basin and $9.4 \times 10^{6}$ ha outside along the Atlantic coast (Stone et al. 1994), was subdivided into 3 ecosystem and landuse types (Table 3): secondary forests; degradedforest/mixed agriculture lands; and pasturelands. We estimated the areas of the 3 types as $17.4,19.4$, and $15.1 \times 10^{6}$ ha, respectively (Schroeder \& Winjum 1995). In like manner, we subdivided the large heterogeneous type called degraded-closed forests by Stone et al. (1994) into 2 parts: agriculture lands and secondary forests (Table 3). These types lie primarily within the former Brazilian Atlantic Forest, and were estimated to have areas of 99.7 and $17.6 \times 10^{6}$ ha, respectively (Schroeder \& Winjum 1995). Overall, the combination of these subdivisions and other major divisions from the map by Stone et al. (1994) produced 12 ecosystem and land-use types used for the Brazil analysis (Table 3).

For C-density, the report characterizing $\mathrm{C}$ in the world's phytomass compiled by Olson et al. (1983) was an important data source. This global scale study resulted in a world vegetation map with grid lines at a spacing of $0.5^{\circ}$ longitude by $0.5^{\circ}$ latitude and aboveground-phytomass data from the late 1970 s. Live plant mass and $C$ were estimated for 47 vegetation types based on a wide variety and extensive number of ecosystem studies (Olson et al. 1983, 1985). Phytomass values were for aboveground biomass; we developed belowground phytomass values from published root to shoot ratios (Schroeder \& Winjum 1995).

In most cases there was a straightforward mapping of Olson classes to those used in this study. However, 2 of the ecosystem types in the map by Stone et al. (1994) had no counterpart in the Olson map. One was degraded-forest/mixed agriculture lands and the second was degraded woodlands. For these types, C-density estimates were developed from other published values as follows. For degraded-forest/mixed agriculture lands, we assumed an average $\mathrm{C}$ density of $25 \mathrm{Mg}$ $\mathrm{C}$ ha $^{-1}$-intermediate between that for secondary forests (40 $\mathrm{Mg} \mathrm{C} \mathrm{ha}^{-1}$ from Olson et al. 1983, 1985) and that for pasturelands (10 $\mathrm{Mg} \mathrm{C} \mathrm{ha}^{-1}$; Fearnside 1992). Degraded woodlands in the tropics are most often developed by repeated burning that lowers the phytomass density and opens the canopy of the woody vegetation (Eiten 1972, Coutinho 1982, Frost \& Robertson 1985). We assumed that if intact woodlands contained $30 \mathrm{Mg} \mathrm{C} \mathrm{ha}^{-1}$ of phytomass, and if agricultural

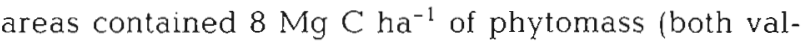
ues from Olson et al. 1983, 1985), then degraded woodlands should be intermediate, i.e. approximately $20 \mathrm{Mg} \mathrm{Cha}^{-1}$ (Table 3).

These values [the Olson set, the Fearnside (1992) value for pasturelands, and the estimates for degraded 
Table 3. Areas and C densities by ecosystem and land-use type for Brazil during 1990

\begin{tabular}{|c|c|c|c|c|c|c|}
\hline \multirow[t]{2}{*}{ Ecosystem and land-use type } & \multirow[t]{2}{*}{ Area $^{\text {(Mha }}$} & \multicolumn{4}{|c|}{ C density $\left(\mathrm{MgC} \mathrm{ha} \mathrm{a}^{-1}\right)$} & \multirow{2}{*}{$\begin{array}{l}\text { C pool } \\
(\mathrm{Pg} \mathrm{C})\end{array}$} \\
\hline & & $\begin{array}{l}\text { Total } \\
\text { phytomass }\end{array}$ & $\begin{array}{l}\text { Litter- } \\
\text { CWD }\end{array}$ & Soil $^{\mathrm{C}}$ & Total & \\
\hline Closed moist forest (TMF) & 352.2 & $1.76^{i}$ & $18^{\circ}$ & 104 & 298 & 104.9 \\
\hline \multicolumn{7}{|l|}{ Recently degraded TMF } \\
\hline Secondary forest & 17.4 & 40 & 4 & 94 & 138 & 2.4 \\
\hline Degraded forest/mixed agriculture & 19.4 & 25 & 3 & $94^{9}$ & 122 & 2.4 \\
\hline Pastureland & 15.1 & 10 & $44^{1}$ & 95 & 149 & 2.2 \\
\hline Other closed forest & 16.4 & $116^{\mathrm{h}}$ & $4^{\mathrm{h}}$ & 100 & 220 & 3.6 \\
\hline \multicolumn{7}{|l|}{ Degraded closed forest } \\
\hline Agriculture & 99.7 & 8 & 0 & 75 & 83 & 8.3 \\
\hline Secondary forest & 17.6 & 40 & 1 & $90^{9}$ & 131 & 2.3 \\
\hline Cerrado woodland & 155.6 & $26^{1}$ & 2 & 60 & 88 & 13.6 \\
\hline Degraded woodland & 33.0 & 20 & 0 & 60 & 80 & 2.7 \\
\hline Savannah/grassland & 74.0 & 6 & 0 & 60 & 66 & 4.8 \\
\hline Degraded savannah (converted to agriculture) & 17.9 & 8 & 0 & $54^{9}$ & 62 & 1.1 \\
\hline Wetland/mangrove & 12.4 & $110^{\mathrm{k}}$ & 0 & 234 & 344 & 4.3 \\
\hline Total & 830.7 & & & & & 152.6 \\
\hline \multicolumn{7}{|c|}{ "Stone et al. (1994), Schroeder \& Winjum (1995), Winjum \& Schroeder (1995) } \\
\hline \multicolumn{7}{|c|}{ 'From Schroeder \& Winjum (1995) } \\
\hline \multicolumn{7}{|c|}{ 'From Zinke et al. (1984) } \\
\hline \multicolumn{7}{|c|}{$\begin{array}{l}\text { 'Mean of estimates from Olson (1983, 1985), } 200 \mathrm{Mg} \mathrm{C} \mathrm{ha}^{-1} \text {; Fearnside (1992), } 191 \mathrm{Mg} \mathrm{C} \mathrm{ha}^{-1} \text {; and Brown \& Lugo (1992), } \\
137 \mathrm{Mg} \mathrm{C} \mathrm{ha}^{-1}\end{array}$} \\
\hline \multicolumn{7}{|c|}{ Mean of estimates ranging from 15 to $22 \mathrm{Mg} \mathrm{C} \mathrm{ha}^{-1}$ (Schroeder \& Winjum 1995) } \\
\hline \multicolumn{7}{|c|}{ 'Mean of estimates ranging from 35 to $52 \mathrm{Mg} \mathrm{C} \mathrm{ha}^{-1}$ (Schroeder \& Winjum 1995) } \\
\hline \multicolumn{7}{|c|}{${ }^{9}$ Assumes $10 \% \mathrm{C}$ loss due to disturbance } \\
\hline \multicolumn{7}{|c|}{ Mean of estimates ranging from 60 to 172 and 2 to $6 \mathrm{Mg} \mathrm{C}^{\mathrm{h}}{ }^{-1}$, respectively (Schroeder \& Winjum 1995) } \\
\hline \multicolumn{7}{|c|}{ Mean of estimates ranging from 22 to $30 \mathrm{Mg} \mathrm{C} \mathrm{ha}^{-1}$ (Schroeder \& Winjum 1995) } \\
\hline \multicolumn{7}{|c|}{ 'Mean of estimates ranging from 3 to $9 \mathrm{Mg} \mathrm{C} \mathrm{ha}^{-1}$ (Schroeder \& Winjum 1995) } \\
\hline Mean of estimates ranging from 30 to $190 \mathrm{Mg}$ & ${ }^{-1}$ (Schroeder \& & Winjum 199 & & & & \\
\hline
\end{tabular}

woodlands] furnished one series of $\mathrm{C}$ densities (Table 3). Carbon values from other sources were also considered, which allowed the calculation of an average estimate of the $C$ pool for some ecosystem and land-use types. For example, $C$ densities for 4 of the types were taken from Fearnside (1992), i.e. closedmoist forests, other-closed forests, cerrado woodlands, and wetland/mangroves (Table 3). In addition, Brown \& Lugo (1992) and Kauffman et al. (1994) gave useful values for closed-moist forests and savanna/grasslands (Table 3). When no other published data were available, however, we used the Olson $\mathrm{C}$ estimates as default values. This approach reflected the moderate confidence (see Table 5) in the available data that resulted from the complexity, size, and diversity of the nation and its vegetation.

A companion report to Olson et al. (1983) provides estimates of soil $\mathrm{C}$ for all of the Olson ecosystem types (Zinke et al. 1984). Again when other published data were not available, we used the Zinke soil-C estimates as default values. These values were also applied to the Stone classes (Table 3 ) to produce estimates of $\mathrm{C}$ density for phytomass, litter-CWD, and soil for each of the ecosystem and land-use types of Brazil (Table 3). As for $\mathrm{SU}_{\mathrm{f}}$ and $\mathrm{US}_{\mathrm{c}}, \mathrm{C}$ densities times the areas provided estimates of the terrestrial-C pools of the nation in the base year 1990 (Table 3).

\subsection{Data uncertainty}

As a qualitative indication of uncertainty in the data used for these analyses, the authors rated their input data sources. Accordingly, T. P. Kolchugina rated $\mathrm{SU}_{\mathrm{f}}$; D. P. Turner, US $\mathrm{C}_{i}$ and P. E. Schroeder, Brazil. Each author provided certainty or reliability ratings for their data on a scale of 1 (very low) to 10 (very high) for 4 key variables and for 4 primary land-use types.

\section{RESULTS}

The terrestrial-C pools for 1990 in the $\mathrm{SU}_{1}, \mathrm{US}_{\mathrm{c}}$, and Brazil were estimated to be 601, 86, and $153 \mathrm{Pg} \mathrm{C}$, respectively (Tables 1, $2 \& 3$; Fig. 2). The total, $840 \mathrm{Pg}$ C, was contained on a land base of $3.7 \times 109$ ha. 

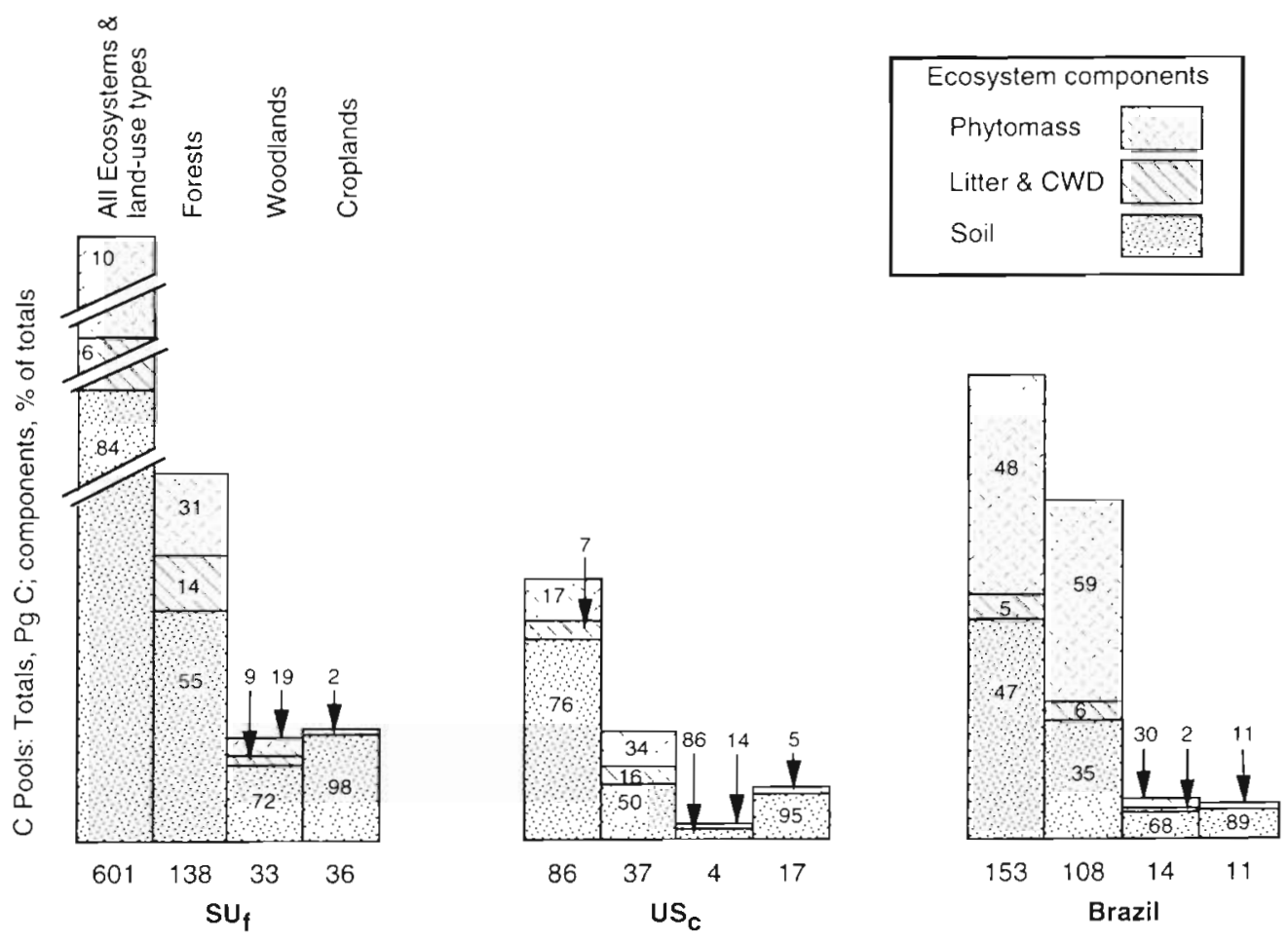

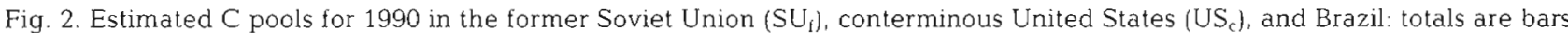
on left and forest, woodland, and cropland pools are the 3 right bars. Each $\mathrm{C}$ pool is divided by percentage into 3 ecosystem components: phytomass; litter and CWD; and soil

\subsection{Ecosystem and land-use types}

The largest C pool among all ecosystem and landuse types for the 3 nations was that for peatlands in the $\mathrm{SU}_{\mathrm{f}}$ at $220 \mathrm{Pg} \mathrm{C}$. This result was largely because of its high soil-C density of $1300 \mathrm{Mg} \mathrm{C}$ ha ${ }^{-1}$ over an area of $165 \times 10^{6}$ ha (Table 1 ). The $\mathrm{C}$ density was also high (344 Mg C ha ${ }^{-1}$ ) for the wetland/mangrove lands in Brazil. This type's C pool, however, is relatively small, about $4 \mathrm{Pg} \mathrm{C}$, since its land area is comparatively low at $12.4 \times 10^{6}$ ha (Table 3 ).

With the above exceptions, forest-C densities and pools were largest among the land cover types within each case study. Forest- $\mathrm{C}$ densities $\left(\mathrm{Mg} \mathrm{C} \mathrm{ha}^{-1}\right)$ were 222 for $\mathrm{SU}_{1}, 184$ for $\mathrm{US}_{\mathrm{c}}$ and 298 for Brazil's tropicalmoist forests. The corresponding $C$ pools were 138,37 , and $105 \mathrm{Pg} \mathrm{C}$ (Tables 1, 2 \& 3). Besides forests, 2 other ecosystem and land-use types were common to the 3 case studies: woodlands and croplands. Woodland-C densities ranged from 88 to $173 \mathrm{Mg} \mathrm{Cha}^{-1}$ (Tables 1,2 \& 3), which resulted in $\mathrm{C}$ pools of about 33,4 , and $14 \mathrm{Pg}$ $\mathrm{C}$, respectively, for the $\mathrm{SU}_{1,} \mathrm{US}_{c}$ and Brazil (Table 4). For croplands, $C$ densities ranged from 82 to $156 \mathrm{Mg} \mathrm{C}$ $\mathrm{ha}^{-1}$ and were strongly based on the amount of soil $\mathrm{C}$ (Tables $1,2 \& 3$ ). The $\mathrm{C}$ pools for croplands within the 3 case studies were, respectively, 36, 17, and $11 \mathrm{Pg} \mathrm{C}$ (Table 4).
For components within ecosystems and land-use types, soil $\mathrm{C}$ was usually the dominant fraction (Tables 1 through 4 ). For example, soil $\mathrm{C}$ represented a range from about 55 to $95 \%$ of the $\mathrm{C}$ pools for most forests, woodlands, and croplands in the 3 case studies (Fig. 2). The one exception was for closed forests in Brazil where it was estimated that only $35 \%$ of the ecosystem-C pool was contained in the soil. The forest and woodland phytomass contained a range of 14 to $59 \%$ of the C pools, while litter and CWD made up a range of 2 to $16 \%$ (Fig. 2).

\subsection{Uncertainty}

Qualitative reliability ratings for data in the case studies resulted in an average rating of about 6 on a scale of 1 (very low) to 10 (very high) (Table 5). Across the 3 studies, the area estimates received a higher assessment of reliability (94 out of a possib]e aggregate rating of 120) than did the C-density estimates (63 to 70). For the ecosystem and land-use types (again out of a possible 120 rating), highest reliability was for the data on croplands (88) with decreased rankings from forests (80) to woodlands (68) to other land uses (59). Comparing the total rating among nations was not valid by this method because personal rating biases cannot be eliminated. 
Table 4. Estimates of $\mathrm{C}$ pools for case study nations during 1990. Values are means or weighted means for common ecosystem and land-use types, national totals, and their basic components. nd: not determined

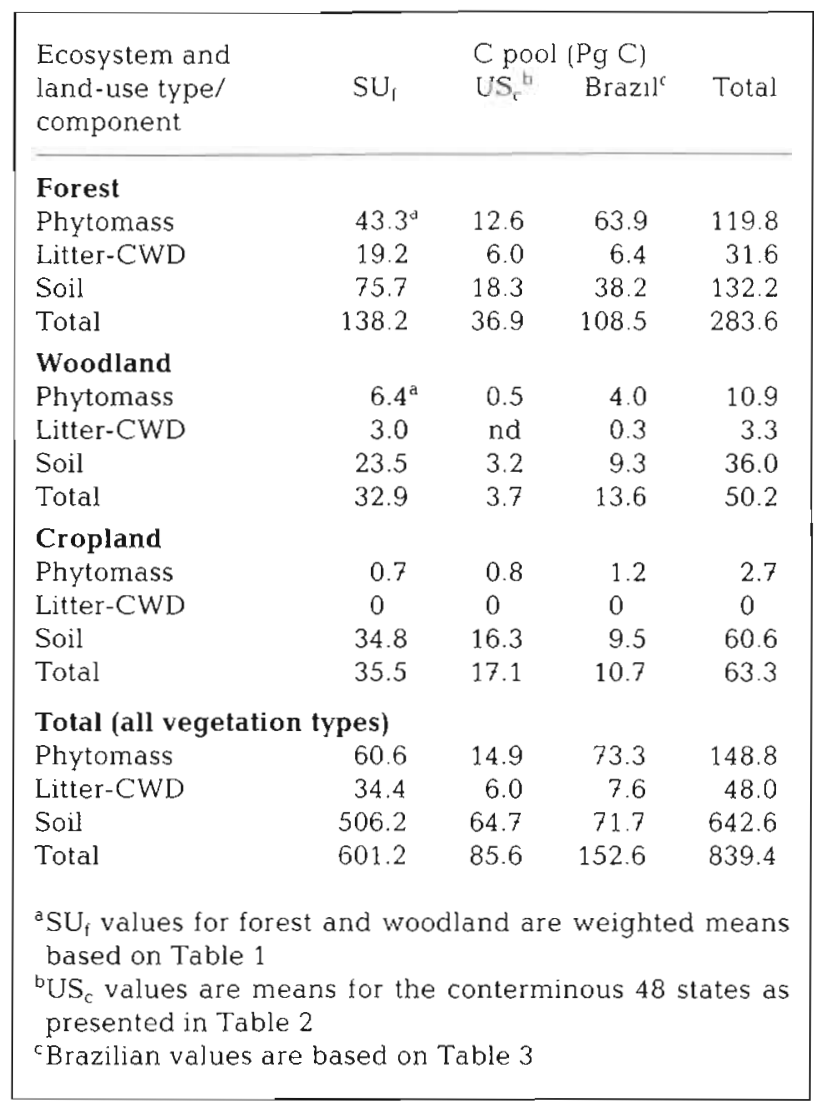

\section{DISCUSSION}

\subsection{Carbon densities and pools}

The terrestrial ecosystems of the world contain an estimated $610 \mathrm{Pg}$ of $\mathrm{C}$ in 'vegetation' and $1580 \mathrm{Pg} \mathrm{C}$ in 'soil and detritus' for a total of $2190 \mathrm{Pg} \mathrm{C}$ (Schimel 1995). Note that estimates for these global pools still vary considerably (e.g. Simpson \& Botkin 1992), and that validation of estimates over large spatial scales remains a significant research issue. Nevertheless, compared to these estimates, the 3 case-study nations contained about $38 \%$ ( $839 \mathrm{Pg} \mathrm{C}$, Table 4 ) of the terrestrial-ecosystem $\mathrm{C}$ in the world on about $29 \%$ of the world's land area (excluding Antarctica). The $\mathrm{SU}_{\mathrm{f}}$ alone, because of its large size and areas of C-rich forests, peatlands, and chernozem soils, contained about $27 \%$ of the world's total terrestrial-C pool or $601 \mathrm{Pg} C$ (Table 1).

For the forests of the world, the $\mathrm{C}$ in phytomass (including all above- and belowground living and dead biomass) and soils (to a depth of $1 \mathrm{~m}$ ) are esti-
Table 5. Reliability ratings by authors ${ }^{d}$ for data used in estimating $C$ pools for the 3 case-study nations. Authors (see 'Methods') rated the 4 key parameters and 4 primary land-use types within each nation. The rating scale ranged from 1 (very low) to 10 (very high)

\begin{tabular}{|c|c|c|c|c|}
\hline \multirow{2}{*}{$\begin{array}{l}\text { Country' } \\
\text { ecosystem and } \\
\text { land-use type }\end{array}$} & \multirow[t]{2}{*}{ Area } & \multicolumn{3}{|c|}{ C density } \\
\hline & & $\begin{array}{c}\text { Phyto- } \\
\text { mass }\end{array}$ & $\begin{array}{l}\text { Litter- } \\
\text { CWD }\end{array}$ & Soil \\
\hline \multicolumn{5}{|l|}{$\mathbf{S U}_{i}$} \\
\hline Forest & 8 & 7 & 5 & 6 \\
\hline Woodland & 6 & 6 & 4 & 6 \\
\hline Cropland & 9 & 8 & 9 & 6 \\
\hline Other & 8 & 5 & 2 & 6 \\
\hline \multicolumn{5}{|l|}{$\mathrm{US}_{\mathrm{c}}$} \\
\hline Forest & 9 & 8 & 4 & 5 \\
\hline Woodland & 9 & 5 & 3 & 3 \\
\hline Cropland & 9 & 4 & 9 & 7 \\
\hline Other & 9 & 3 & 3 & 3 \\
\hline \multicolumn{5}{|l|}{ Brazil } \\
\hline Forest & 8 & 7 & 6 & 7 \\
\hline Woodland & 8 & 6 & 5 & 7 \\
\hline Cropland & 6 & 5 & 9 & 7 \\
\hline Other & 5 & 4 & 4 & 7 \\
\hline \multicolumn{5}{|l|}{ Totals by: } \\
\hline Parameter & 94 & 68 & 63 & 70 \\
\hline \multirow[t]{2}{*}{ Land-use type } & Forest & Woodland & Cropland & Other \\
\hline & 80 & 68 & 88 & 59 \\
\hline
\end{tabular}

mated to be 359 and $787 \mathrm{Pg} \mathrm{C}$, respectively. The total, therefore, is $1146 \mathrm{Pg} \mathrm{C}$ on $4.16 \times 10^{9}$ ha (Dixon et al. 1994). The aggregate estimate of $284 \mathrm{Pg} \mathrm{C}$ for the forests of this analysis (Table 4 ) was about $25 \%$ of the respective world total on $30 \%$ of the forest lands. As in other reported comparisons (Apps et al. 1993, Brown et al. 1993, Ojima et al. 1993, Olson et al. 1983, 1985, Waring \& Schlesinger 1985), forest phytomass is the dominant component of total phytomass over many large geographical areas. Despite containing a large proportion of the world's remaining primary forests, the area-weighted mean for $\mathrm{C}$ density of forest areas in this analysis (238 $\mathrm{Mg} \mathrm{C} \mathrm{ha}^{-1}$ ) was lower than the global mean of $275 \mathrm{Mg} \mathrm{C} \mathrm{ha}^{-1}$ reported by Dixon et al. (1994). A possible factor in this difference is the increased attention here to the effects of land use on $\mathrm{C}$ pools.

The highest average phytomass density for forests was $173 \mathrm{Mg} \mathrm{C} \mathrm{ha-1} \mathrm{in} \mathrm{the} \mathrm{Brazilian} \mathrm{tropical-moist} \mathrm{forest}$ ecosystem. This density was more than double that for forests of the 2 northerly nations, i.e. the $\mathrm{SU}_{\mathrm{f}}$ with $70 \mathrm{Mg}$ $\mathrm{Cha}^{-1}$ and the $\mathrm{US}_{\mathrm{c}}$ with $63 \mathrm{Mg} \mathrm{C}^{-1}$. With regards to $\mathrm{C}$ densities of litter and CWD, the forest ecosystems of the $\mathrm{SU}_{\mathrm{f}}$ and $\mathrm{US}_{\mathrm{C}}$ were highest with estimates similar to each other at 31 and $30 \mathrm{Mg} \mathrm{C}^{-1}$, respectively. Comparing 
soil C density, $\mathrm{SU}_{\mathrm{f}}$ forests contained the highest level at $122 \mathrm{Mg} \mathrm{Cha}^{-1}$ versus $\mathrm{US}_{\mathrm{c}}$ at $91 \mathrm{Mg} \mathrm{Cha}^{-1}$ and Brazil at $104 \mathrm{Mg} \mathrm{C} \mathrm{ha}^{-1}$. In studies of deep soil conditions (to depths of $8 \mathrm{~m}$ ) in Amazonian forest lands in Brazil's state of Pará, however, Nepstad et al. (1994) found soil-C densities (excluding roots) up to $300 \mathrm{Mg} \mathrm{Cha}{ }^{-1}$. The authors speculate that such densities may be widespread in Amazonian forests. If true, forest soil- $\mathrm{C}$ densities beyond conventional $1 \mathrm{~m}$ depths should be evaluated and compared. Even without treating deeper soils, the total ecosystem- $C$ density for the Brazilian tropical-moist forest type (294 Mg C ha-1) is highest among the forests in the 3 countries (Tables $3 \& 4$ ).

For woodlands and croplands, the $\mathrm{SU}_{\mathrm{f}}$ ecosystems had the highest $C$ densities at 173 and $156 \mathrm{Mg} \mathrm{Cha}^{-1}$, respectively (Table 4). However, these densities largely rested on the high levels of soil C $(123 \mathrm{Mg} \mathrm{C}$ $\mathrm{ha}^{-1}$ for woodlands and $153 \mathrm{Mg} \mathrm{C} \mathrm{ha}^{-1}$ for croplands) in the $\mathrm{C}$-rich chernozem soils typical of the temperate forest steppe region. The high soil- $C$ contents are in part an artifact of measurement in the $\mathrm{SU}_{\mathrm{f}}$ to depths greater than $1 \mathrm{~m}$. Zinke et al. (1984) reported 102 and $99 \mathrm{Mg} \mathrm{C}$ $\mathrm{ha}^{-1}$ for the surface $1 \mathrm{~m}$ of soil in the boreal dry bush and the cool temperate desert bush, respectively. The $\mathrm{SU}_{i}$ soil-C densities were also higher than the broad world averages reported by Waring \& Schlesinger (1985) of $69 \mathrm{Mg} \mathrm{Cha}^{-1}$, or $70 \%$ of the total C density (i.e. including live and dead phytomass), for woodlands and $127 \mathrm{Mg} \mathrm{Cha}^{-1}$, or $96 \%$ of the total, for agricultural lands.

The $C$ densities of forests reported in this study reflect both the influence of climate and land use on terrestrial ecosystems (Table 4 ). The results are consistent with literature surveys that report colder climates of the boreal and temperate latitudes to generally have ecosystems with more $\mathrm{C}$ stored belowground than above, while tropical ecosystems in warm climates exhibit the opposite trend (Barbour et al. 1987). The observation of greater aboveground mean $\mathrm{C}$ storage in the forests of Brazil also in part reflects a much larger proportion of the total forest area as primary forests. The average $C$ storage on managed forest lands tends to be lower than on unmanaged lands because the stand age-class distribution is shifted toward the younger, more productive, age classes that store less $\mathrm{C}$ (Dewar 1991).

The 2 largest single pools, soil $\mathrm{C}$ in peatlands of the $\mathrm{SU}_{\mathrm{f}}(212 \mathrm{Pg})$ and the phytomass of the tropical-moist forests in Brazil (176 Pg), are vulnerable to release to the atmosphere. The peatland-soil $C$ is vulnerable to global warming, which is projected to be greatest at the higher latitudes (Houghton et al. 1996, Oechel \& Vourlitis 1997). The tropical-moist forest $C$ is vulnerable to deforestation (Houghton 1990). The large size of these pools means that losses could be sustained over a relatively long period and could contribute significantly to the continued increase of atmospheric $\mathrm{CO}_{2}$ anticipated over the next century (Schimel et al. 1995).

\subsection{Variation in methodology}

Even within these 3 nations, the methods for estimating C pools varied widely. As noted by Birdsey (1992), data useful for these types of estimates are often collected in prior years and usually for other reasons. Similarly, definitions (e.g. forests above), and approaches to sampling related to intensity, frequency, and protocols, are not consistent among nations nor consistent over time. Different biological disciplines may be involved in data collection with a consequent need to translate across disciplines (e.g. Albrektson 1980). Data from ecological studies may be biased toward relatively robust or vigorous plots (Brown \& Lugo 1992, Simpson \& Botkin 1992).

Information on forest inventories is particularly important in development of national-level $\mathrm{C}$ budgets (Turner et al. 1995). The economic importance of forests means that many national governments maintain an updated forest inventory (FAO 1996), however, the quantity and quality of inventory data varies widely. In the U.S., a large grid of permanent plots $(130000)$ is surveyed periodically (10 уг) and an estimate of uncertainty is associated with each volume and area estimate (USDA 1992, Peterson \& Turner 1993). The forest inventory of the $\mathrm{SU}_{\mathrm{f}}$ is also based on repeated surveys, but details of inventory protocols are not well documented. An additional problem is variation in the area covered as new areas are brought into the inventory (Shvidenko \& Nilsson 1994). In Brazil, intensive forest inventories are still under development. Even differences between primary and secondary forests have been difficult to quantify in some locations due to the intermixing with shifting agriculture (Schroeder \& Winjum 1995). Use of coarse resolution satellite imagery for land cover mapping and inventory development, as in this study, will increasingly be supplanted by monitoring efforts using satellite-borne sensors with finer spatial and spectral resolution. The finer spatial resolution will tend to reduce overestimates of deforestation (Skole \& Tucker 1993), and more extensive use of different and narrower spectral bands will permit better differentiation of successional stages (Moran et al. 1994).

\subsection{Uncertainty}

Estimating $\mathrm{C}$ pools at large spatial scales required combining information from a variety of sources with 
varying reliability. Robinson (1989) states, regarding estimating trace gas fluxes, that 'error enters estimation through uncertainties and biases in the data, and compounds as data are combined to draw (often) lengthy chains of inferences' Thus, it is useful to know the uncertainty associated with each component of a national-level estimate and also the uncertainty associated with the total estimate (Cieszewski et al. 1996).

If the variances around the value of each component in the chain of calculations are known, several methods exist to address the level of uncertainty of the estimate. If the coefficients of variation ( $\mathrm{CVs}$ ) are small enough (e.g. <0.3) and the components are independent of each other, a first order Taylor series expansion is often used to approximate the variance of the estimate as a combination of the variance of its components. However, as Robinson (1989) points out, with larger CVs and/or correlations among the components, higher order terms cannot be ignored and this approach is insufficient. Monte Carlo simulation may serve as an alternative if sufficient information is available concerning the distribution and correlation of the components. Good characterization, however, depends upon large representative samples, preferable taken randomly and with uniform methods. At the large spatial scales in national or global analyses, obtaining data in such a manner is virtually impossible at this time.

In terrestrial ecology, the issue is further complicated by an almost universally low level of information about the $\mathrm{C}$ density below ground in roots and soil. Although data are becoming increasingly available (Jackson et al. 1996), the root component is often estimated by multiplying aboveground phytomass by a factor developed from even more limited measurements of root phytomass. Soil $\mathrm{C}$ is likewise receiving increasing attention, however, a particularly critical problem is the poor understanding of changes in soil $\mathrm{C}$ after disturbance. A recent workshop on responses of temperate zone forest soils to forest management concluded that insufficient information is available to make broad generalizations about relationships between forest stand age class and the soil-C pool (Frey 1996). Linking soil-pedon databases to maps with high spatial resolution has potential for improved soil-C mapping (Kern et al. 1998); however, close attention to spatial scale is needed in these analyses to avoid erroneous interpretations (Davidson \& Lefebvre 1993).

In a few cases now, calculations of uncertainty for specific biomass pools have been made (e.g. Brown et al. 1995). These analyses suggest the possibilities of designing a sampling protocol that is adequate to reduce uncertainty to a specified level. The optimal case may be where satellite remote sensing at high spatial resolution (e.g. $30 \mathrm{~m}$; Cohen et al. 1996) is employed to accurately map land cover or land use. Such remote sensing along with intensive sampling on the ground can generate statistically reliable estimates for $C$ pools associated with each land-cover type.

\section{CONCLUSIONS}

Refining the estimate of the global terrestrial-C pool and its spatial distribution is a continuing scientific need. Improvements on the estimates through a nation-by-nation approach are ongoing. Toward that goal, we found that making estimates for $C$ pools in 3 large national-level areas representing the boreal, temperate, and tropical regions required combining data from a variety of disparate sources often with unquantified levels of uncertainty. Nevertheless, a common approach, consisting of (1) classifying national land bases into ecosystem and land-use types, (2) assigning a mean $C$ density to each land cover type from some form of plot-level measurements, and (3) quantifying the area of each type with traditional mapping approaches or satellite remote sensing, proved effective. Forest ecosystems tended to have a relatively large proportion of total carbon in each country and we considered information on stand ageclass distribution in forests critical due to the large changes in living and dead biomass over the course of stand development. Since some of the largest $C$ pools identified in this study are potential long-term sources of $C$ to the atmosphere, further study of their magnitudes is warranted. Increased attention to quantifying uncertainty is desirable in studies of large scale $\mathrm{C}$ pools if they are to make a contribution to understanding the global $\mathrm{C}$ cycle and to the development of policies regarding global climate change.

Acknowledgements. The research described in this paper has been funded by the U.S. Environmental Protection Agency. The paper has been prepared at the EPA National Health and Ecological Effects Research Laboratory/Western Ecology Division in Corvallis, Oregon, USA, through Interagency Agreement No. DW12934530/Grant PNW 91-0051. It has been subjected to the Agency's peer and administrative review process and has been approved for publication. Portions of the paper will also appear in papers submitted to other peer-reviewed journals. Mention of trade names or commercial products does not constitute endorsement or recommendation for use

\section{LITERATURE CITED}

Adams DM, Alig RJ, Anderson DK (1992) Future prospects for western Washington's timber supply. University of Washington, College of Forest Resources, Seattle

Alban DH, Perala DA (1992) Carbon storage in Lake States aspen ecosystems. Can J For Res 22:1107-1110 
Albrektson A (1980) Relations between tree biomass fractions and conventional silvicultural measurements. Ecol Bull 32: $315-327$

Apps MJ, Kurz WA, Luxmoore RJ, Nilsson LO, Sedjo RA Schmidt R, Simpson LG, Vinson TS (1993) Boreal forests and tundra. Water Air Soil Pollut 70:39-53

Barbour MG, Burk JH, Pitts WD (1987) Terrestrial plant ecology. Benjamin/Cummings Publishing Company, Menlo Park, CA

Bazilevich NI (1986) Biological productivity of soil-vegetation formations in the U.S.S.R. Bull Acad Sci USSR Geogr Ser 2:49-66

Birdsey RA (1992) Changes in forest carbon storage from increasing forest area and timber growth, Chap 3. In Sampson RN, Hair D (eds) Forests and global change Vol 1, Opportunities for increasing forest cover. American Forests, Washington, DC, p 23-39

Botch MS, Kobak KI, Vinson TS, Kolchugina TP (1995) Carbon pools and accumulation in peatland of the former Soviet Union. Global Biogeochem Cycles 9(1):37-46

Brown IF, Martinelli LA, Thomas WW, Moreira MZ, Ferreira CAC, Victoria RA (1995) Uncertainty in the biomass of Amazonian forests: an example from Rondônia, Brazil. For Ecol Manage 75:175-189

Brown S, Hall CAS, Knabe W, Raich J, Trexler MC, Woomer P (1993) Tropical forests: their past, present, and potential future role in the terrestrial carbon budget. Water Air Soil Pollut 70:71-94

Brown S, Lugo AE (1992) Aboveground biomass estimates for tropical moist forests of the Brazilian Amazon. Interciencia $17: 8-18$

Cairns MA, Kolchugina TP, Turner DP, Winjum JK (eds) (1995) The contribution of forest land use to total national carbon flux: case studies in the former Soviet Union, United States, Mexico, and Brazil. EPA/600/R-95/044, US Environmental Protection Agency, Environmental Research Laboratory, Corvallis, OR

Cherdantsev GN (1961) Map: arable land in the U.S.S.R. in 1954. Scale 1:50,000,000. In: Cole JP (ed) A geography of the U.S.S.R. - background to a planned economy. FC German, Butterworths, London, p 85

Cieszewski CJ, Turner DP, Phillips DL (1996) Statistical analysis of error propagation in national level carbon budgets. In: Mower HT, Czaplewski RL, Hamre RH (eds) Spatial accuracy assessment in natural resources and environmental sciences: second international symposium. General Technical Report RM-GTR-277 USDA. Forest Service, Rocky Mountain Forest and Range Experimental Station, Fort Collins, CO, p 649-658

Cohen WB, Harmon ME, Wallin DO, Fiorella M (1996) Two decades of carbon flux from forests of the Pacific Northwest. BioScience 46(11):836-844

Coutinho LM (1982) Ecological effects of fire in Brazilian cerrado. In: Huntley BJ, Walker BH (eds) Ecology of tropical savannas. Springer-Verlag. New York, p 273-291

Davidson EA, Lefebvre PA (1993) Estimating regional carbon stocks and spatially covarying edaphic factors using soil maps at three scales. Biogeochemistry 22:107-131

Denning AS, Fung IY, Randall D (1995) Latitudinal gradient of atmospheric $\mathrm{CO}_{2}$ due to season exchange with land biota. Nature 376:240-243

Dewar RC (1991) Analytical model of carbon storage in the trees, soils, and wood products of managed forests. Tree Physiol 8:239-258

Dixon RK, Brown S, Houghton RA, Solomon AM, Trexler MC, Wisniewski J (1994) Carbon pools and flux of global forest ecosystems. Science 263:185-190
Eiten G (1972) The cerrado vegetation of Brazil. Bot Rev $38: 201-341$

Eyre FH (ed) (1980) Forest cover types of the United States and Canada. Society of American Foresters, Washington, DC

FAO (Food and Agriculture Organization of the United Nations) (1995) Forest resources assessment 1990: global synthesis. FAO Forestry Paper 124, FAO, Rome

FAO (Food and Agriculture Organization of the United Nations) (1996) Forest resources assessment 1990: survey of tropical forest cover and study of change processes. FAO Forestry Paper 130, FAO, Rome

Fearnside PM (1992) Greenhouse gas emissions from deforestation in the Brazilian Amazon. Carbon emissions and sequestration in forests: case studies from seven developing countries. Vol 2, LBL-32758, UC-402. US Environmental Protection Agency, Climate Change Division, Washington, DC, and Lawrence Berkeley Laboratory, Energy and Environment Division, Berkeley, CA

Frey SD (1996) Workshop on effects of management on forest soil carbon: a report. USDA Forest Service general technical report NE217. USDA Forest Service, Radnor, PA

Frost PGH, Robertson F (1985) The ecological effects of fire in savannas. In: Walker $\mathrm{BH}$ (ed) Determinants of tropical savannas. Int Union Biol Sci Monogr Series, No. 3. IRL Press, Oxford, p 93-140

Gaston GG, Kolchugina TP (1995) Estimates of phytomass and net primary productivity in terrestrial ecosystems of the former Soviet Union identified by classified global vegetation index. World Resour Rev 7(4):525-540

Gaston GG, Kolchugina TP, Vinson TS (1993) Potential effect of no-till management on carbon in the agricultural soils of the former Soviet Union. Agric Ecosyst Environ 45: 295-309

Haynes RW (1990) An analysis of the timber situation in the United States: 1989-2040. USDA Forest Service General Technical Report RM-199. USDA Forest Service, Fort Collins, $\mathrm{CO}$

Houghton JT, Meira Filho LG, Callander BA, Harris N, Kattenberg A, Maskell K (eds) (1996) Climate change 1995: the science of climate change. University Press. Cambridge

Houghton RA (1990) The future role of tropical forests in affecting the carbon dioxide concentration of the atmosphere. Ambio 19(4):204-209

Isayev AS, Korovin GN, Utkin Al, Pryazhnikov AA, Zamolotchikov DG (1993) Deposition in assessment of stores and annual sequestration of carbon in phytomass of forest ecosystems of Russia. Lesovedenie 5:3-10

Jackson RB, Canadell J, Ehleringer JR, Mooney HA, Sala OE, Schulze ED (1996) A global analysis of root distributions for terrestrial biomes. Oecologia 108:389-411

Johnson DW (1992) Effects of forest management on soil carbon storage. Water Air Soil Pollut 64:83-120

Kauffman JB, Cummings DL, Ward DE (1994) Relationship of fire, biomass, and nutrient dynamics along a vegetation gradient in the Brazilian cerrado. J Ecol 82:519-531

Kauppi PE, Mielikäinen KKK, Kuusela K (1992) Biomass and carbon budget of European forests, 1971 to 1990. Science 256:70-74

Kauppi PE, Posch M, Hänninen P, Henttonen HM, Ihalainen A, Lappalainen E, Starr M, Tamminen P (1997) Carbon reservoirs in peatlands and forests in the boreal regions of Finland. Silva Fenn 31(1):13-25

Kern JS (1994) Spatial patterns of soil organic carbon in the contiquous United States. Soil Sci Soc Am J 58:439-455

Kern JS, Turner DP, Dodson RF (1998) Spatial patterns of soll 
organic carbon pool size in the Northwestern United States. In: Lal R, Kimble JM, Follet RF, Stewart BA (eds) Soil processes and the carbon cycle, Chap 3. CRC Press, Boca Raton, FL, p 29-43

King GA (1993) Net primary productivity of non-forested lands. In: Turner DP, Lee JJ, Koerper GJ, Barker JR (eds) The forest sector carbon budget of the United States: carbon pools and flux under alternative policy options. EPA/600/393/093. US Environmental Protection Agency, Environmental Research Laboratory, Corvallis, OR, p 179-194

Kobak KI (1988) Biotical components of carbon cycle. Hydrometeoizdat, Leningrad

Kolchugina TP, Vinson TS (1993a) Carbon sources and sinks in the forest biomes of the former Soviet Union. Global Biogeochem Cycles 7:291-304

Kolchugina TP, Vinson TS (1993b) Comparison of two methods to assess the carbon budget of forest biomes in the former Soviet Union. Water Air Soil Pollut 70:207-221

Kolchugina TP, Vinson TS (1993c) Framework to quantify the natural terrestrial carbon cycle of the former Soviet Union. In: Vinson TS, Kolchugina TP (eds) Proceedings of the workshop on carbon cycling in boreal forests and subartic ecosystems, 9-14 September, 1991, Corvallis, OR. US Environmental Protection Agency, Environmental Research Laboratory, Corvallis, OR, p 257-273

Kolchugina TP, Vinson TS (1995) Role of Russian forests in the global carbon balance. Ambio 24(5):258-264

Kolchugina TP, Vinson TS, Gaston GG, Rozhkov VA, Shvidenko AZ (1995) Carbon pools, fluxes, and sequestration potential in soils of the former Soviet Union. In: Lal R, Kimble J, Levine E, Stewart B (eds) Soil management and the greenhouse effect. CRC Press, Boca Raton, FL, p 25-40

Laarman JG, Sedjo RA (1992) Global forests: issues for six billion people. McGraw-Hill, New York

MacLean CD, Ohmann JL, Bassett PM (1991) Preliminary timber resource statistics for southwest Washington. Resource Bulletin PNW-RB-177 US Department of Agriculture, Forest Service, Pacific Northwest Research Station, Portland, OR

Mann LK (1986) Changes in soil carbon storage after cultivation. Soil Sci 142:279-288

McGuire AD, Melillo JM, Joyce LA, Kicklighter DW, Grace AL, Moore B Ill, Vorosmarty CJ (1992) Interactions between carbon and nitrogen dynamics in estimating net primary productivity for potential vegetation in North America. Global Biogeochem Cycles 6:101-124

Mills JR, Kincaid JC (1992) The aggregate timberland assessment system-ATLAS: a comprehensive timber projection model. USDA Forest Service General Technical Report PNW-GTR-281. USDA. Forest Service, Portland, OR

Moran EF, Brondizio E, Mausel P, Wu Y (1994) Integrating Amazonian vegetation, land-use, and satellite data. BioScience 44:329-338

Nepstad DC, de Carvalho CR, Davidson EA, Jipp PH, Lefebvre PA, Negrelros DH, da Silva ED, Stone TA, Trumbore SE, Velra $S$ (1994) The role of deep roots in the hydrological and carbon cycles of Amazonian forests and pastures. Nature 372:666-669

NYT (New York Times) (1988) Atlas of the world. Times Books, New York

Oechel WC, Vourlitis GL (1997) Climate change in northern latitudes: alterations in ecosystem structure and function and effects on carbon sequestration. In: Oechel WC, Callaghan T, Gilmanov TG, Holten JI, Maxwell B, Molau $U$, Sveinbjornsson B (eds) Global change and arctic terrestrial ecosystems. Springer, New York, p 381-401

Ojima DS, Dirks BOM, Glenn EP, Owensby CE, Scurlock JO
(1993) Assessment of $C$ budget for grasslands and drylands of the world. Water Air Soil Pollut 70:95-109

Olson JS, Watts JA, Allison LJ (1983) Carbon in live vegetation of major world ecosystems. Report ORNL-5862. Oak Ridge National Laboratory, Oak Ridge, TN

Olson JS, Watts JA, Allison LJ (1985) Major world ecosystem complexes ranked by carbon in live vegetation: a database. Report DOE.NDP-017 Oak Ridge National Laboratory, Environmental Sciences Division, Oak Ridge, TN

Peterson CE (1993) Biomass and carbon for woodlands in the Western United States. In: Turner DP, Lee JJ, Koerper GJ, Barker JR (eds) The forest sector carbon budget of the United States: carbon pools and flux under alternative policy options. EPA/600/3-93/093. US Environmental Protection Agency, Environmental Research Laboratory, Corvallis, OR, p 143-149

Peterson CE, Turner DP (1993) Uncertainty in country-wide forest biomass estimates. In: Kanninen $M$ (ed) The carbon balance of the world's forest ecosystems: towards a global assessment. May 11-15, 1992. Publications of the Academy of Finland, Helsinki, p 252-255

Powell DS, Faulkner JL, Darr DR, Zhu Z, MacCleery DW (1993) Forest resources of United States, 1992. USDA Forest Service, Genera] Technical Report RM-234. USDA Forest Service, Fort Collins, CO

Robinson JM (1989) On uncertainty in the computation of global emissions from biomass burning. Clim Change 14 : 243-262

Ryabchikov AM (ed) (1988) Map: geographical belts and zonal types of landscapes of the world. Scale 1:15,000,000. School of Geography, Moscow State University, Moscow

Schimel DS (1995) Terrestrial ecosystems and the carbon cycle. Global Change Biol 1(1):77-91

Schimel DS, Enting IG, Heimann M, Wigley TML, Raynaud D. Alves D, Siegenthaler U (1995) $\mathrm{CO}_{2}$ and the carbon cycle. In: Climate change 1994: radiative forcing of climate change and an evaluation of the IPCC IS92 emission scenarios. Cambridge University Press, Cambridge, p 35-71

Schroeder PE, Winjum JK (1995) Assessing Brazil's carbon budget: I. Biotic carbon pools. For Ecol Manage 75:77-86

SCS (Soil Conservation Service, US Department of Agriculture) (1987) Basic statistics, 1982 National Resources Inventory. Statistical Bulletin Number 756. Iowa State University, Statistical Laboratory, Ames, IA

Sessions J (coordinator) (1991) Timber for Oregon's tomorrow: the 1989 update. Oregon State University, College of Forestry, Forest Research Laboratory, Corvallis

Shvidenko AZ, Nilsson S (1994) What do we know about the Siberian forests? Ambio 23:396-404

Siegenthaler U, Oeschger $\mathrm{H}$ (1987) Biospheric $\mathrm{CO}_{2}$ emissions during the past 200 years reconstructed by deconvolution of ice core data. Tellus 39B:140-154

Simpson LG, Botkin DB (1992) Vegetation, the global carbon cycle, and global measures. In: Dunette DA, O'Brien RJ (eds) The science of global change, the impact of human activities on the environment. ACS Symposium Series 483 . American Chemical Society, Washington, DC, p 413-425

Skole D, Tucker C (1993) Tropical deforestation and habitat fragmentation in the Amazon: satellite data from 19781988. Science 260:1905-1910

Stone TA, Schlesinger P, Houghton RA, Woodwell GM, Merrill A (1994) A map of the vegetation of South America based on satellite imagery. Photogramm Eng Remote Sens 60:541-551

Subak S, Raskin P, von Hippel D (1993) National greenhouse gas accounts: current anthropogenic sources and sinks. Clim Change 25:15-58 
Turner DP, Baumgardner GA (1995) United States case study In: Cairns MA, Kolchugina TP, Turner DP, Winjum JK (eds) The contribution of forest land use to total national carbon flux: case studies in the former Soviet Union, United States, Mexico, and Brazil. EPA/600/R-95/044. US Enviromental Protection Agency, Enviromental Research Laboratory, Corvallis, OR, p 61-84

Turner DP, Koerper GJ, Harmon M, Lee JJ (1995) A carbon budget for forests of the conterminous United States. Ecol Appl 5(2):421-436

Turner DP, Lee JJ, Koerper G, Barker JR (1993) The forest sector carbon budget of the United States: carbon pools and flux under alternative policy options. EPA/600/ 3-93/093. US Enviromental Protection Agency, Environmental Research Laboratory, Corvallis, OR

Turner DP, Winjum JK, Kolchugina TP, Cairns MA (1997) Accounting for biological and anthropogenic factors in national land-base carbon budgets. Ambio 26:220-226

USDA (US Department of Agriculture) (1989) An analysis of the land base situation in the United States: 1989-2040. USDA Forest Service, General Technical Report RM-181 USA Forest Service, Fort Collins, CO

USDA (US Department of Agriculture) (1992) Forest Service resource inventories: an overview. USDA Forest Service, Forest Inventory, Economics, and Recreation Research, Washington, DC

USSR (USSR State Forestry Committee) (1990) Forest Fund of the USSR, Moscow: 1. USSR State Forestry Committee, Moscow

Editorial responsibility: Brent Yarnal,

University Park, Pennsylvania, USA
Vogt KA, Grier CC, Vogt DJ (1986) Production, turnover, and nutrient dynamics of above- and below-ground detritus of world forests. Adv Ecol Res 15:303-377

Vorobyov GI (ed) (1985) Forestry encyclopedia, Vol 1 Sovetskaya Encyclopedia Press, Moscow

Waddell KL, Oswald DD, Powell DS (1989) Forest statistics of the United States. USDA Resource Bulletin PNW-RB-168 USDA Forest Service, Pacific Northwest Research Station, Portland, OR

Waring RH, Schlesinger WH (1985) Forest ecosystems: concepts and management. Academic Press, Orlando, FL

Winjum JK, Dixon RK, Schroeder PE (1993) Forest management and carbon storage: an analysis of 12 key nations. Water Air Soil Pollut 70:239-257

Winjum JK, Schroeder PE (1995) Brazil case study. In: Cairns MA, Kolchugina TP, Turner DP, Winjum JK (eds) The contribution of forest land use to total national carbon flux: case studies in the former Soviet Union, United States, Mexico, and Brazil. EPA/600/R-95/044. US Environmental Protection Agency, Environmental Research Laboratory, Corvallis, OR, p 116-158

WRI (World Resources Institute) (1992) World resources 1992-93: a guide to the global environment. Oxford University Press, Oxford

Zinke PJ, Stangenberger AG, Post WM, Emanual WR, Olson JS (1984) Worldwide organic soil carbon and nitrogen data. Report ORNL/TM-8857, Environmental Sciences Division Publication No. 2212. Oak Ridge National Laboratory, Oak Ridge, TN

Submitted: August 23, 1996; Accepted: December 5, 1997 Proofs received from author(s): February 23, 1998 